\title{
Altered islet amyloid polypeptide (amylin) gene expression in rat models of diabetes
}

\author{
D. Bretherton-Watt ${ }^{1}$, M.A.Ghatei ${ }^{1}$, S. R. Bloom ${ }^{1}$, H. Jamal ${ }^{1}$, G. J. M. Ferrier ${ }^{2}$, S. I. Girgis ${ }^{2}$ and S. Legon ${ }^{2}$ \\ Departments of ${ }^{1}$ Medicine and ${ }^{2}$ Chemical Pathology, The Royal Postgraduate Medical School, Hammersmith Hospital, London, UK
}

Summary. The response of the islet amyloid polypeptide gene to chronic dexamethasone treatment in adult rats was investigated. After 12 daily injections, rats were severely underweight and fasting blood glucose levels were elevated. When pancreatic mRNA was analysed, a 16-fold elevation in islet amyloid polypeptide mRNA was observed with only a fourfold increase in insulin mRNA levels. Pancreatic islet amyloid polypeptide and insulin mRNA levels were also determined 12 days after streptozotocin treatment. In these rats, which were not severely diabetic, the reduction in islet amyloid poly- peptide mRNA levels was sixfold less than the reduction in insulin mRNA levels. In both these models of diabetes the ratio of islet amyloid polypeptide to insulin mRNA levels was raised. This would not be expected if the physiological role of islet amyloid polypeptide is as a simple hyperglycaemic agent opposing insulin action or release.

Key words: Islet amyloid polypeptide, amylin, Type 2 (noninsulin-dependent) diabetes mellitus, mRNA, streptozotocin, dexamethasone, rat.
A 37 amino acid peptide with homology to calcitonin gene related peptide (CGRP) has recently been characterised from the pancreatic amyloid deposits of a Type 2 (non-insulin-dependent) diabetic patient [1] and from an insulinoma [2]. This peptide is now known as islet amyloid polypeptide (IAPP) [2], or amylin [3]. IAPP opposes the action of insulin on isolated muscle preparations [3] and inhibits insulin release from rat islets in vitro [4]. Using a cloned DNA probe representing the rat IAPP coding sequence, we have recently found IAPP to be present in the stomach as well as the pancreas [5]. A variety of evidence thus suggests that this peptide may play an important role in the control of carbohydrate metabolism. We therefore decided to study the expression of the IAPP gene in the rat pancreas after treatment with agents known to affect carbohydrate metabolism. In particular, we wanted to know whether IAPP and insulin levels could be regulated independently and whether induced peripheral insulin resistance would lead to changes in the pancreas which might have relevance to amyloid deposition in man.

\section{Materials and methods}

\section{Drug treatments}

Adult male Wistar rats of $125-150 \mathrm{~g}$ were divided into 3 groups: (1) controls $(n=5)$ fed ad libitum on standard rat chow, (2) dexamethasone $(n=5) 2 \mathrm{mg} / \mathrm{kg}$ injected i.p. each day for 12 days, and (3) streptozotocin treatment $(n=24) 60 \mathrm{mg} / \mathrm{kg}$ injected i.v. 12 days prior to analysis. After treatment, rats were starved overnight and killed by cervical dislocation after ether anaesthesia. Blood was taken for glucose measurements and the pancreas was dissected and frozen under liquid nitrogen for RNA extraction.

\section{RNA analysis}

Total RNA was prepared from the frozen tissues and analysed by Northern blotting with rat IAPP and insulin probes as previously [5]. However, to minimise handling, polyadenylated RNA was not purified in the present experiments and $30 \mu \mathrm{g}$ of total RNA was loaded onto each track of these gels. Stringent washing conditions ( $60 \mathrm{~min}$ at $60^{\circ}$ in $30 \mathrm{mmol} / 1 \mathrm{NaCl}, 3 \mathrm{mmol} / 1 \mathrm{Na}$ citrate $\mathrm{pH} 7.0$ and $0.2 \%$ SDS) 


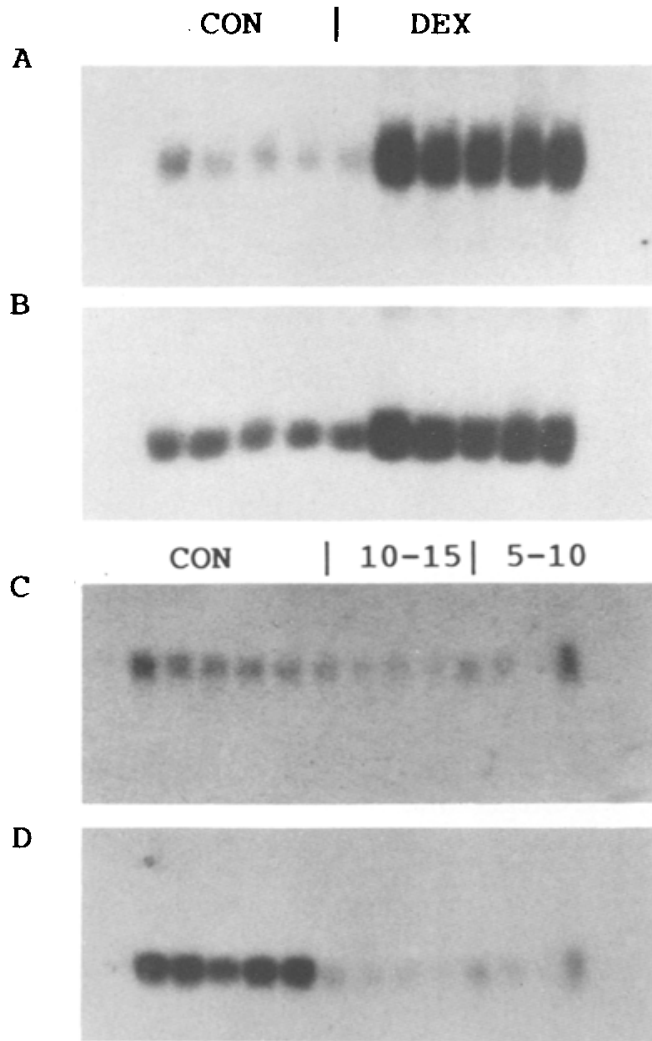

Fig. 1. Northern blot analysis of pancreatic RNA. Aliquots of $30 \mu \mathrm{g}$ of total pancreatic RNA were probed for IAPP (Panels A and C) and insulin mRNAs (Panels $\mathbf{B}$ and D). Panels $\mathbf{A}$ and $\mathbf{B}$ show the analysis of 5 control rats (left) with 5 from the dexamethasone treated group (right). Panels $\mathbf{C}$ and $\mathbf{D}$ show the analysis of 5 control rats (left) with 8 from the streptozotocin treated group - 5 with blood glucoses in the range $10-15 \mathrm{mmol} / 1$ (centre) and 3 in the range $5-10 \mathrm{mmol} / 1$

were used for all blots. Blots were probed first for IAPP then stripped by incubating for $10 \mathrm{~min}$ at $80^{\circ}$ in $10 \mathrm{mmol} / 1 \mathrm{Tris} / \mathrm{HCl} \mathrm{pH} 7.6$, $100 \mu \mathrm{mol} / 1$ EDTA before reprobing for insulin which gives approximately 10-fold higher signal intensities in a normal pancreas [5].

Pre-flashed Kodak XAR-5 films were exposed to the filters at $-70^{\circ}$ with Kodak X-omatic regular intensifying screens and fluorograms were scanned using a Gelman DCD-16 densitometer. The area under the curve for each signal peak was computed and results were expressed as mean \pm SEM. Statistical analysis was carried out using the Student's unpaired $t$-test.

\section{Results}

\section{Dexamethasone}

After 12 daily injections of dexamethasone, rats were severely underweight (treated average $162 \mathrm{~g}$, control average $259 \mathrm{~g}$ ). Fasting blood glucose levels were slightly elevated (average $9.0 \pm 0.7 \mathrm{mmol} / \mathrm{l}$, controls $5.4 \pm$ $0.3 \mathrm{mmol} / \mathrm{l}$ ). When pancreatic RNA was analysed by Northern blotting (Fig. 1 A), IAPP mRNA was found to be increased 16-fold (controls $106 \pm 24$ (mean \pm SEM), dexamethasone treated $1736 \pm 166, n=5, p<0.001$ ). After stripping the filter and reprobing, insulin mRNA levels were found to be increased fourfold (Fig.1B, controls $116 \pm 6$, dexamethasone treated $474 \pm 60, n=5$, $p<0.001$ ).

\section{Partial streptozotocin}

The intention was to select from this group, a series of rats with moderate rather than severe diabetes. A control group of 5 rats (mean blood glucose $5.4 \mathrm{mmol} / 1$ ) and a group of 5 treated rats with blood glucose levels in the range $10-15 \mathrm{mmol} / 1$ were chosen. Total pancreatic RNA was analysed by Northern blotting and hybridised with a probe specific for rat IAPP (Fig.1C). The filter was then stripped and reprobed for rat insulin (Fig.1D). IAPP mRNA levels were lower than control values with an average 3.5 -fold reduction in the treated group (controls 207 \pm 44 , treated $60 \pm 21, n=5$, $p<0.001$ ). However, insulin mRNA levels were profoundly affected with a 23 -fold reduction (controls $929 \pm 93$, treated $41 \pm 16, n=5, p<0.001$ ). A further 3 rats had blood glucose levels in the range 5-10 mmol/l and these were also analysed (Fig. $1 \mathrm{C}$ and $1 \mathrm{D})$. Results showed an average twofold reduction in IAPP mRNA (controls $207 \pm 44$, treated $85 \pm 73$ ) compared to a 12-fold reduction in insulin mRNA (controls $929 \pm 93$, treated $75 \pm 48$ ).

\section{Discussion}

Three pieces of evidence have suggested that over-expression of IAPP may be the cause of Type 2 diabetes in man. Firstly, the peptide was isolated from pancreatic amyloid deposits [1] suggesting some abnormality associated with its expression. Secondly, the peptide was found to oppose the action of insulin on skeletal muscle preparations [3] and thirdly, it was found to inhibit insulin release [4]. Although there is no wholly satisfactory model for Type 2 diabetes in the rat, dexamethasone and partial streptozotocin treatment produce conditions having elements in common with this condition and these were therefore investigated using the technique of Northern blotting. In these studies we have probed first for IAPP and then stripped and reprobed the blots for insulin mRNA which is more abundant and gives a band close to but not overlapping the IAPP mRNA band [5]. The ratio between the two signals is thus not subject to accidental variation in sample loading or transfer which can make Northern blots difficult to interpret.

Dexamethasone treatment caused a fourfold increase in insulin mRNA and a 16-fold increase in IAPP mRNA. Dexamethasone causes hyperglycaemia so the increase in insulin levels was expected. However, the greater elevation in IAPP mRNA levels is less easy to understand. One possibility is that dexa- 
methasone stimulates the IAPP gene directly and this might be a contributory factor in the development of peripheral insulin resistance. Alternatively, if the increase in IAPP mRNA levels represents a response to the hyperglycaemia then it suggests a model for the development of Type 2 diabetes. An initially mild peripheral insulin resistance might cause an elevation of pancreatic IAPP gene transcription. Elevated IAPP would then disrupt the normal pulsatile release of insulin, exacerbating the insulin resistance [6]. Over the course of many years, this downward spiral would continue leading ultimately to diabetic symptoms, pancreatic amyloidosis and severe impairment of islet function. Such a model would remain tenable even if it were to be shown that serum IAPP levels in Type 2 diabetes are insufficient to affect insulin action in peripheral tissues.

When the streptozotocin treated rats were analysed, the reduction in IAPP mRNA levels was sixfold less than that in insulin mRNA. This may represent the survival of a sub-population of $B$ cells expressing higher levels of IAPP relative to insulin mRNA or it may represent the response of normal $B$ cells to the situation after streptozotocin treatment. In both the diabetic situations which we have studied we have seen an increased level of IAPP mRNA relative to insulin mRNA. If the only physiological role of IAPP is to oppose insulin release and/or activity then it is difficult to understand why whis ratio should be elevated when the need for insulin activity is greatest. The demands of glucose homeostasis would seem to require suppression of IAPP synthesis in this situation. This apparent paradox makes us cautious in accepting that the activities of IAPP reported so far adequately reflect its physiological role.
Acknowledgements. We wish to thank Dr. G.Caldwell for help with streptozotocin treatments, Miss. A.M.Pierson for help with dissections, Dr. M. Alevizaki for useful discussions and The British Diabetic Association for financial support.

\section{References}

1. Cooper GJS, Willis AC, Clark A, Turner RC, Sim RB, Reid KBM (1987) Purification and characterisation of a peptide from amyloid rich pancreases of type 2 diabetic patients. Proc Natl Acad Sci USA 84: 8628-8632

2. Westermark P, Wernstedt C, Wilander E, Hayden DW, O'Brien TD, Johnson KH (1987) Amyloid fibrils in human insulinoma and islets of Langerhans of the diabetic cat are derived from a neuropeptide like protein also present in normal islet cells. Proc Natl Acad Sci USA 84: 3881-3885

3. Leighton B, Cooper GJS (1988) Pancreatic amylin and calcitonin gene related peptide cause resistance to insulin in skeletal muscle in vitro. Nature 335: 632-635

4. Ohsawa H, Kanatsuka A, Yamaguchi T, Makino H, Yoshida S (1989) Islet amyloid polypeptide inhibits glucose stimulated insulin secretion from isolated rat pancreatic islets. Biochem Biophys Res Commun 160: 961-967

5. Ferrier GJM, Pierson AM, Jones PM, Bloom SR, Girgis SI, Legon S (1989) Expression of the rat amylin (IAPP/DAP) gene. J Mol Endocrinol 3: R1-R4

6. Polonsky KS, Given BD, Hirsch LJ, Tillil H, Shapiro ET, Beebe C, Frank BH, Galloway JA, van Cauter E (1988) Abnormal patterns of insulin secretion in non-insulin-dependent diabetes mellitus. $\mathrm{N}$ Engl J Med 318: 1231-1239

Received: 29 August 1989

Dr. S. Legon

Department of Chemical Pathology

The Royal Postgraduate Medical School

Hammersmith Hospital

DuCane Road

London W12 ONN

UK 